\title{
ANALISIS PENGARUH BAHAN BAKAR ALTERNATIF PADA LEMARI PENGASAP IKAN TERHADAP KUALITAS PRODUK HASIL ASAPAN
}

\author{
Setyawan Dwi Nugroho ${ }^{1,2}$, Sudjito Soeparman², Lilis Yuliati' \\ ${ }_{1}^{1}$ Politeknik Kelautan dan Perikanan Sidoarjo, Sidoarjo, Indonesia \\ 2Universitas Brawijaya, Malang, Indonesia. \\ (031) 8911380 \\ E-mail: setya12n@gmail.com
}

\begin{abstract}
This study was conducted to determine the effect of the amount of fuel in the combustion chamber on the fish smoking kiln to temperature and temperature distribution in the smoke room as well as the quality of the smoked fish. This study used 3 types of fuel those are dry coconut shell, coconut fiber and sugarcane pulp briquette. Temperature needed in the smoke room for 3 hours is $80^{\circ} \mathrm{C}$, and the fish smoked is milkfish. The result showed that to achieve the same smoking temperature, it required the amount of dry coconut shell as much as 1045 grams, while the coconut fiber as much as 1730 grams and sugarcane pulp briquette as much as 2055 grams. The temperature of each fishing point is relatively even with a maximum temperature difference of $1.38 \%$, while the difference between the setting temperature and the temperature at the maximum fish points is $8.88 \%$. It can be concluded that the heat value, particle density rate and combustion rate (heat release) of fuel affect the amount and distribution of fuel to the temperature change in the fish smoking room in the fish smoking kiln. The quality of smoked fish products with 3 types of fuels meets SNI 2725.1.2009.
\end{abstract}

Keywords: Coconut shell, coconut fiber, Briquettes, smoking kiln, smoked fish

\section{PENDAHULUAN}

Ikan asap merupakan hasil produk olahan dibidang perikanan yang menggunakan lemari pengasap ikan sebagai pembangkit energi panas yang diperoleh dari pembakaran bahan bakar. Beban panas lemari pengasap ikan diperoleh dari laju pengumpanan sejumlah bahan bakar dengan nilai panas tertentu tiap satuan luas atau volume [1]. Permasalahan yang sering dihadapi oleh masyakarat pengasap ikan yaitu tingkat kematangan hasil asapan ikan yang tidak seragam. Ini merupakan akibat dari proses pengasapan ikan yang tidak memperhatikan distribusi temperatur dalam ruang pengasapan dan laju pengumpanan jumlah bahan bakar pada saat proses pengasapan ikan [2].

Bahan bakar pada proses pengasapan ikan merupakan faktor penting yang menentukan kualitas hasil asapan ikan. Tempurung kelapa merupakan bahan bakar yang selama ini banyak digunakan untuk pengasapan ikan. Selain termasuk golongan kayu yang keras, tempurung kelapa apabila melalui proses pembakaran secara langsung dengan udara terbatas akan menghasilkan arang dengan kualitas yang cukup tinggi. Dimana asap yang dihasilkan melimpah dengan waktu pembakaran yang lama dan temperatur yang dihasilkan tinggi. Oleh karena itu tempurung kelapa dianggap bahan bakar yang cocok untuk pengasapan ikan [3]. Tetapi ketersediaan tempurung kelapa semakin berkurang, sementara kebutuhannya terus meningkat [4]. Karena itu perlu dicari bahan bakar alternatif untuk proses pengasapan ikan.

Penelitian ini dilakukan untuk mengetahui pengaruh jumlah bahan bakar alternatif dalam ruang bakar pada lemari pengasap ikan terhadap kualitas ikan asap. Perbedaan jenis bahan bakar akan mengakibatkan perbedaan pada nilai kalor dan karakteristik pembakarannya, serta kualitas gas asap yang dihasilkan. Hal-hal tersebut di atas akan 
mempengaruhi kualitas ikan asap yang pengasap juga dilengkapi dengan pengarah dihasilkan. Karena itu perlu dilakukan asap yang berfungsi untuk meratakan penelitian proses pengasapan ikan dengan distribusi gas hasil pembakaran (gas asap) jenis bahan bakar alternatif yang berbeda didalam ruang pengasap. Lemari pengasap untuk mendapatkan proses pengasapan ikan ikan terbuat dari rangka besi siku dan setiap yang efektif dan efisian serta menghasilkan dindingnya terbuat dari plat galvalum yang produk ikan asap yang memenuhi standar SNI dilapisi dengan glasswoll yang berfungsi 2725.1:2009 tentang ikan asap.

\section{METODOLOGI PENELITIAN}

Bahan bakar yang digunakan dalam penelitian ini yaitu tempurung kelapa, dan sebagai bahan bakar alternatif digunakan serabut kelapa dan briket ampas tebu. Ikan bandeng yang diasap memiliki ukuran panjang $30 \mathrm{~cm}$ dan jumlah ikan untuk setiap proses pengasapan adalah 6 ekor. Bahan bakar dan ikan bandeng segar yang digunakan dalam penelitian ini berturut - turut dapat dilihat pada Gambar 1 dan 2.

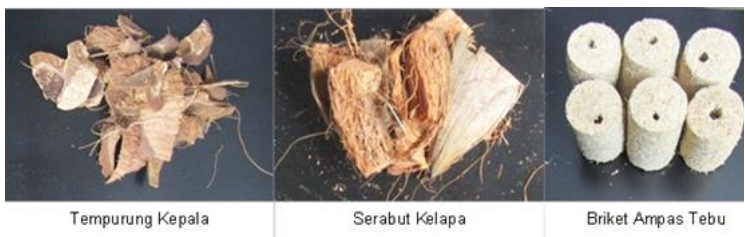

Gambar 1. Jenis bahan bakar pengasapan ikan

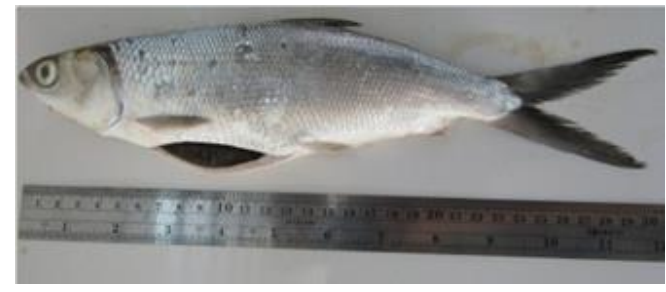

Gambar 2. Ikan bandeng segar

Alat pengasap ikan yang digunakan dalam penelitian ini berbentuk lemari dengan dimensi ukuran $400 \mathrm{~mm} \times 300 \mathrm{~mm} \times 1350 \mathrm{~mm}$ dan tinggi cerobong $4000 \mathrm{~mm}$, yang terdiri dari tiga bagian utama yaitu ruang bakar, ruang pengasap dan cerobong asap. Ruang bakar berfungsi sebagai tempat pembakaran bahan bakar yang akan digunakan untuk pengasapan ikan. Ruang pengasap berfungsi untuk mendistribusikan gas asap dan panas pada ikan, dan cerobong asap berfungsi sebagai saluran pembuangan gas asap. Lemari sebagai isolator panas untuk mengurangi heat loss dari gas hasil pembakaran ke lingkungan. Nilai kalor dari masing-masing jenis bahan bakar yang digunakan dalam proses pengasapan dapat dilihat pada Tabel 1.

Enam ekor ikan bandeng diletakkan dalam lemari pengasap dengan kepala berada di bagian bawah. Ikan diletakkan berjajar dengan susunan 2 baris dan 3 kolom. Gambar instalasi penelitian dan distribusi peletakan ikan ditunjukkan pada Gambar 3. Untuk memulai pembakaran, bahan bakar diletakkan di luar ruang bakar. Bahar bakar disiram dengan minyak goreng dan dinyalakan dengan api. Selanjutnya bahan bakar dibiarkan menyala selama 2 menit hingga pembakaran menjadi stabil, kemudian dimasukkan ke ruang bakar. Penelitian ini dilakukan dengan satu tahap pemanasan dimana bahan bakar dipanaskan untuk menaikkan temperatur ruang pengasapan dari temperatur ruang (sebesar $29^{\circ} \mathrm{C}$ atau $30^{\circ} \mathrm{C}$ ) menjadi $80^{\circ} \mathrm{C}$. Alat ukur temperatur yang digunakan adalah data logger temperatur dan termokopel yang dihubungkan dengan ruang pengasap pada lemari pengasap ikan serta pembacaan grafik hubungan temperatur terhadap waktu yaitu dengan menggunakan pembacaan komputer. Setelah bahan bakar dalam ruang bakar hampir habis, ditunjukkan dengan penurunan temperatur, lalu ditambahkan bahan bakar dengan jumlah tertentu untuk menjaga agar temperatur ruang pengasapan menjadi konstan pada temperatur $80^{\circ} \mathrm{C}$. Prosedur penyalaan, pengumpanan bahan bakar dan pengkondisian temperatur ruang pengasap pada temperatur $80^{\circ} \mathrm{C}$ seperti tersebut diatas dilakukan untuk setiap jenis bahan bakar. Proses pengasapan pada temperatur $80^{\circ} \mathrm{C}$ dilakukan selama 3 jam. 
Tabel 1. Nilai kalor bahan bakar

\begin{tabular}{clc}
\hline No & Jenis bahan bakar & Nilai kalor $(\mathrm{kcal} / \mathrm{kg})$ \\
\hline 1 & $\begin{array}{l}\text { Tempurung } \\
\text { kelapa }\end{array}$ & 4340 \\
\hline 2 & Serabut kelapa & 3860 \\
\hline 3 & Briket ampas tebu & 3520 \\
\hline
\end{tabular}

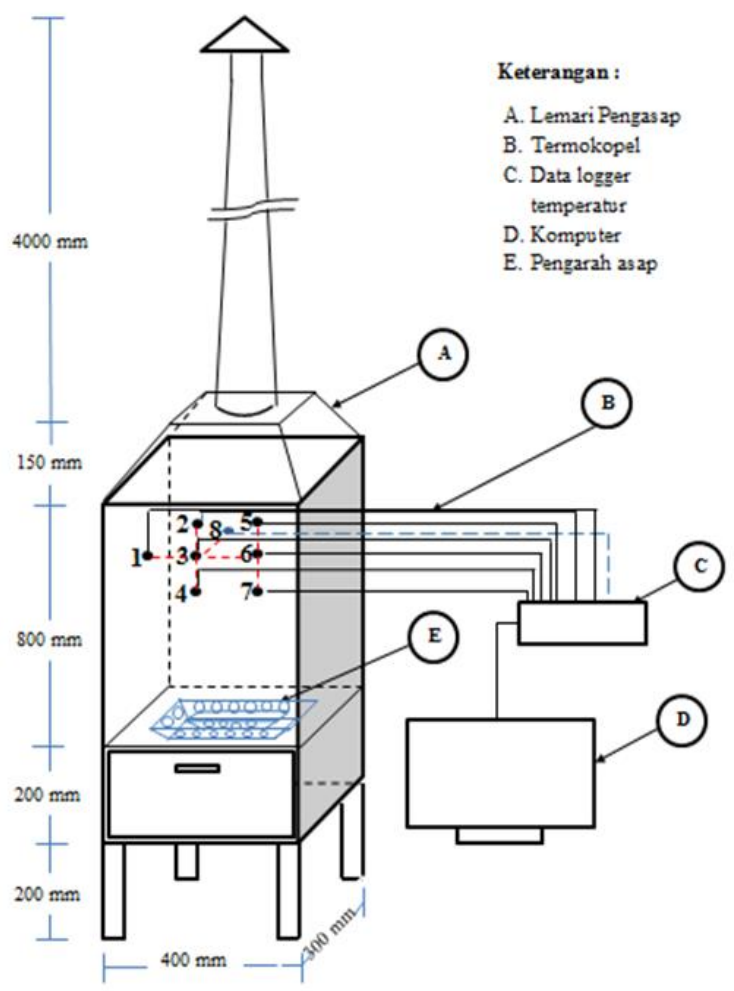

Gambar 3. Skema instalasi peralatan penelitian

Pada setiap proses pengasapan dengan variasi bahan bakar, distribusi temperatur ruang pengasapan diukur pada beberapa titik peletakan ikan seperti di tunjukkan pada Gambar 3. Pengukuran temperatur dilakukan dengan menggunakan termokopel tipe WRNT02CA (K) dengan dimensi M6 x $1 \times 2000 \mathrm{~mm}$ yang dihubungkan dengan data logger (tipe USB-4718, Advantech, 8 channel). Delapan termokopel digunakan untuk mengukur temperatur dalam lemari pengasap. Termokopel no. 1, 3, 6 dan 8 digunakan untuk mengukur temperatur pada bagian badan (tengah) ikan, termokopel no. 2 dan 5 untuk mengukur temperatur pada bagian ekor ikan, sedangkan termokopel no. 4 dan 7 mengukur temperatur di bagian kepala ikan. Titik-titik peletakan termokopel dapat dilihat pada Gambar 3.

Setelah proses pengasapan selesai, dilakukan pengujian kualitas ikan yang telah diasap. Pengujian yang dilakukan meliputi pengujian proksimate ikan untuk mengetahui kadar air, kadar abu, kandungan protein dan lemak, serta pengujian organopeltik untuk menilai kenampakan, bau, rasa dan tekstur ikan. Pengujian organoleptik dilakukan 10 orang mahasiswa tingkat pertama dibawah pengawasan Kepala Laboratorium Pengujian Mutu Hasil Perikanan Politeknik Kelautan dan Perikanan Sidoarjo

\section{HASIL DAN PEMBAHASAN}

Pembakaran bahan bakar untuk mencapai dan mempertahankan temperatur ruang pengasapan sebesar $80^{\circ} \mathrm{C}$ ditentukan dengan cara trial and error. Untuk setiap jenis bahan bakar dilakukan pengumpanan awal (pengumpanan l) untuk meningkatkan temperatur ruang pengasapan (sebesar $29^{\circ} \mathrm{C}$ $30^{\circ} \mathrm{C}$ ) hingga mencapai temperatur $80^{\circ} \mathrm{C}$. Selanjutnya dilakukan pengumpanan bahan bakar (pengumpanan II, III dan seterusnya) untuk menjaga temperatur ruang pengasapan pada $80^{\circ} \mathrm{C}$ selama $3 \mathrm{jam}$. Jumlah bahan bakar yang diperlukan untuk proses pemanasan dan pengasapan dapat dilihat pada Tabel 2.

Tabel 2. Kebutuhan jumlah bahan bakar

\begin{tabular}{|c|c|c|c|c|}
\hline No & $\begin{array}{c}\text { Jenis dan massa } \\
\text { bakan bakar } \\
\text { diperlukan }\end{array}$ & $\begin{array}{l}\text { Tempu- } \\
\text { rung } \\
\text { kelapa }\end{array}$ & $\begin{array}{l}\text { Serabut } \\
\text { kelapa }\end{array}$ & $\begin{array}{c}\text { Briket } \\
\text { ampas tebu }\end{array}$ \\
\hline 1 & $\begin{array}{l}\text { Massa bahan } \\
\text { bakar untuk } \\
\text { pemanasan dari } \\
\mathrm{T}_{\text {ruang }}-80^{\circ} \mathrm{C}(\mathrm{gr})\end{array}$ & 145 & 180 & 195 \\
\hline 2 & $\begin{array}{l}\text { Massa bahan } \\
\text { bakar untuk } \\
\text { pengasapan pada } \\
\mathrm{T}=80^{\circ} \mathrm{C}(\mathrm{gr})\end{array}$ & 900 & 1550 & 1875 \\
\hline 3 & $\begin{array}{l}\text { Total massa BB } \\
\text { untuk pemanasan } \\
\& \text { pengasapan (gr) }\end{array}$ & 1045 & 1730 & 2070 \\
\hline
\end{tabular}


Massa bahan bakar untuk pemanasan dari Truang $-80^{\circ} \mathrm{C}$ sama dengan massa bahan bakar pada Pengumpanan I, berturut-turut sebesar $145 \mathrm{gr}, 180 \mathrm{gr}$ dan $195 \mathrm{gr}$ untuk bahan bakar tempurung kelapa, serabut kelapa dan briket ampas tebu. Selanjutnya massa bahan bakar untuk pengasapan pada temperatur $80^{\circ} \mathrm{C}$ selama 3 jam dapat dilihat pada baris no. 2. Massa bahan bakar tersebut merupakan jumlah massa pada pengumpanan II, III dan seterusnya sampai proses pengasapan selesai. Massa bahan bakar per pengumpanan untuk bahan bakar tempurung kelapa, serabut kelapa dan briket ampas tebu adalah sebesar $45 \mathrm{gr}, 50 \mathrm{gr}$ dan $75 \mathrm{gr}$ dengan jumlah pengumpanan berturut-turut sebanyak 20, 31 dan 25 kali. Pengumpanan bahan bakar ke II, III dan seterusnya dapat dihitung dengan perhitungan jumlah bahan bakar $\mathrm{x}$ jumlah pengumpanan bahan bakar. Sehingga total kebutuhan bahan bakar adalah jumlah pengumpaan bahan bakar ke I ditambahkan dengan jumlah bahan bakar pada pengumpanan ke II, II dan seterusnya. Total kebutuhan massa bahan bakar untuk proses pengasapan secara keseluruhan dapat dilihat pada baris no. 3 .

Dari ketiga jenis bahan bakar yang digunakan, tempurung kelapa memiliki ratarata waktu pengumpanan bahan bakar yang paling lambat dibandingkan serabut kelapa dan briket ampas tebu. Hal ini dipengaruhi tingkat kerapatan partikel tempurung kelapa yang padat sehingga mengakibatkan kecepatan pembakarannya (dm/dt, laju perubahan massa terhadap waktu) menjadi kecil. Walaupun laju pembakarannya lebih rendah, temperatur ruang pengasapan tetap sama dengan temperatur saat menggunakan bahan bakar lain, karena tempurung kelapa memiliki nilai kalor yang lebih tinggi dibandingkan bahan bakar yang lain. Penggunaan bahan bakar yang paling hemat dalam proses pengasapan secara berturutturut adalah tempurung kelapa, serabut kelapa dan briket ampas tebu. Hal ini dipengaruhi oleh besarnya nilai kalor / heating value jenis bahan bakar yang digunakan, sebagaimana ditunjukkan pada Tabel 1. Semakin besar nilai kalornya maka semakin besar kalor yang dihasilkan dari proses pembakaran bahan bakar tersebut, sehingga kebutuhan bahan bakar untuk mencapai temperatur yang dibutuhkan adalah semakin sedikit [6].

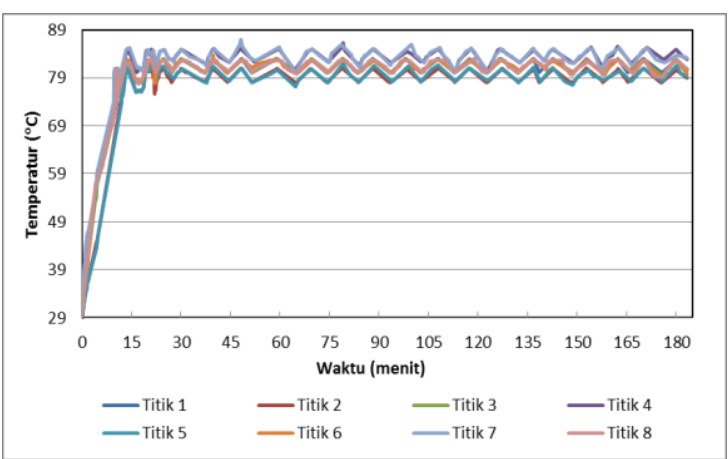

a. Bahan bakar tempurung kelapa

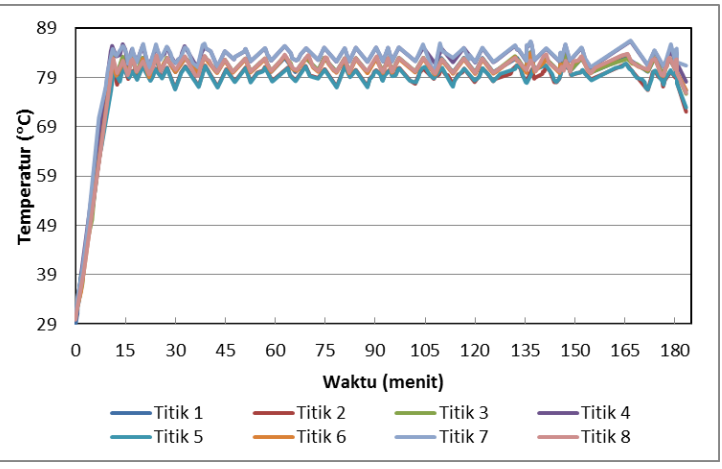

b. Bahan bakar serabut kelapa

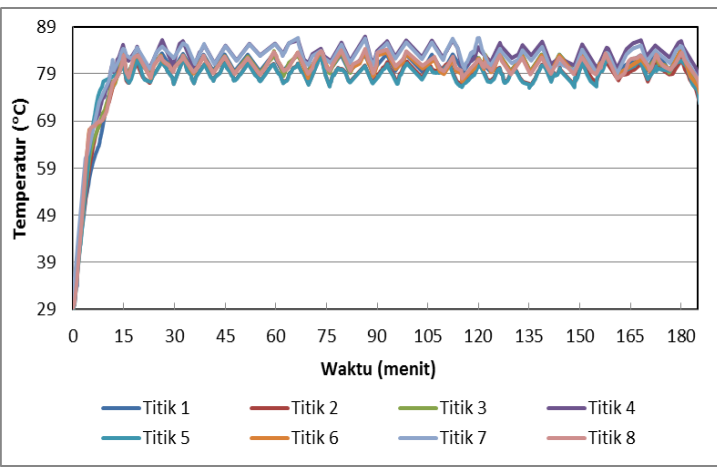

c. Bahan bakar briket ampas tebu

Gambar 4. Besar dan distribusi temperatur sebagai fungsi waktu di dalam ruang pengasap 
Besarnya temperatur ruang pengasapan dan distribusi temperatur disetiap titik pengukuran untuk 3 jenis bahan bakar yaitu tempurung kelapa, serabut kelapa dan briket ampas tebu dapat dilihat pada Gambar 4. Gambar 4 menunjukkan bahwa gradien temperatur yang paling besar dalam ruang pengasapan pada saat pemanasan dari temperatur ruang hingga $80^{\circ} \mathrm{C}$ terjadi pada pembakaran serabut kelapa, sedangkan gradien temperatur dalam lemari pengasap dengan bahan bakar tempurung kelapa dan briket ampas tebu hampir sama. Hal ini menunjukkan bahwa laju pelepasan kalor pada pembakaran serabut kelapa lebih besar. Dimana besarnya laju pelepasan kalor tergantung pada besarnya nilai kalor bahan bakar dan laju pembakaran.

Ruang pengasapan yang mencapai temperatur $80^{\circ} \mathrm{C}$ terlebih dulu, berturut-turut terjadi pada ruang pengasapan dengan bahan bakar serabut kelapa, tempurung kelapa dan briket ampas tebu, yaitu pada 11,42; 13,42 dan 14,08 menit. Setelah mencapai temperatur $\pm 80^{\circ} \mathrm{C}$, temperatur ruang pengasapan dijaga konstan pada nilai tersebut. Hal ini dilakukan dengan cara menambahkan sejumlah bahan bakar ke ruang bakar saat mulai terjadi penurunan temperatur yang mengindikasikan mulai habisnya bahan bakar dalam ruang bakar.

Gambar 4 juga menunjukkan distribusi atau keseragaman temperatur disetiap titik peletakan ikan. Keseragaman temperatur disetiap titik peletakan ikan merupakan hal yang sangat penting untuk mendapatkan kualitas ikan yang seragam dan baik. Perbedaan besarnya temperatur pada titik-titik peletakan ikan akan mengakibatkan buruknya kualitas ikan asap, karena kondisi ini mengakibatkan sebagian ikan terlalu matang atau gosong sementara sebagian lainnya masih belum matang, sehingga tidak memenuhi kriteria kualitas ikan asap sesuai dengan SNI 2725.1.2009 yabg mencakup tentang kenampakan, bau, rasa dan tekstur. Dari Gambar 4 dapat diketahui bahwa temperatur pada bagian kepala, badan dan ekor ikan tidak sama. Temperatur pada bagian kepala ikan (titik 4 dan 7) paling besar bila dibandingkan dengan temperatur badan (titik 1, 3, 6 dan 8) ataupun temperatur ekor (titik 2 dan 5). Hal ini disebabkan kepala ikan terletak dibawah dan jaraknya paling dekat dengan sumber panas. Semakin ke atas temperatur ruangan semakin kecil. Pada ketinggian yang sama, temperatur ruang pengasap hampir sama di setiap titik peletakan ikan. Hal ini ditunjukkan dengan berhimpitnya kurva distribusi temperatur pada bagian ikan yang sama. Kurva T1 berhimpit dengan kurva T3, T6 dan T8, demikian juga kurva T4 berhimpit dengan T7, dan selanjutnya kurva T2 berhimpit dengan kurva T7. Keseragaman temperatur pada setiap titik peletakkan ikan dipengaruhi oleh jumlah, ukuran dan distribusi bahan bakar di dalam ruang bakar. Sedangkan perbedaan temperatur terhadap temperatur setting dipengaruhi oleh posisi titik pada arah vertikal dan fluktuasi temperatur karena penambahan bahan bakar [5].

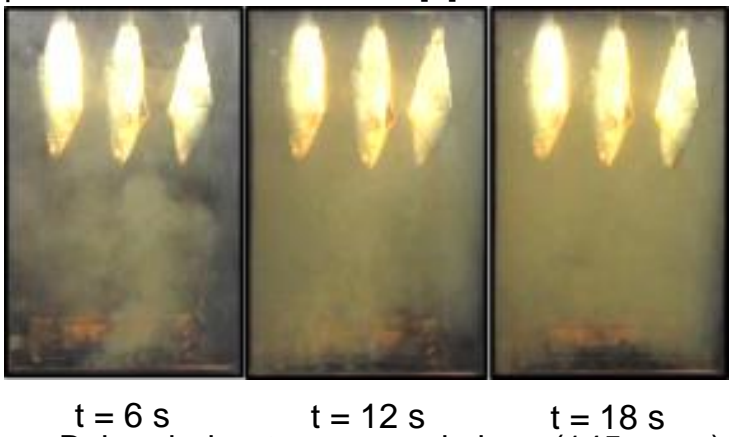

a. Bahan bakar tempurung kelapa (145 gram)

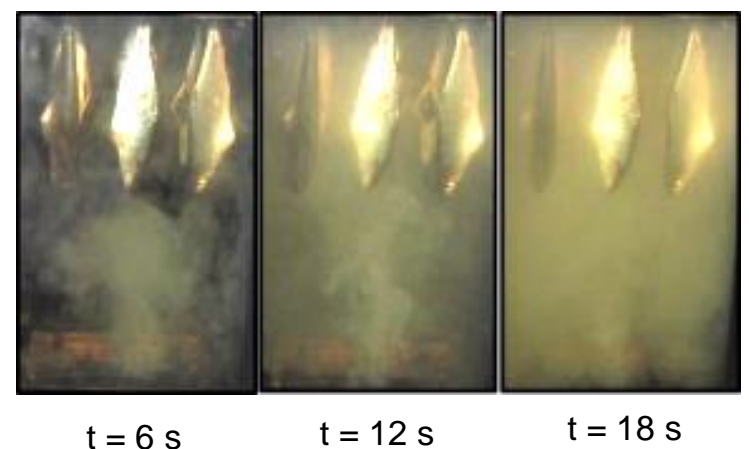

b. Bahan bakar serabut kelapa (180 gram) 


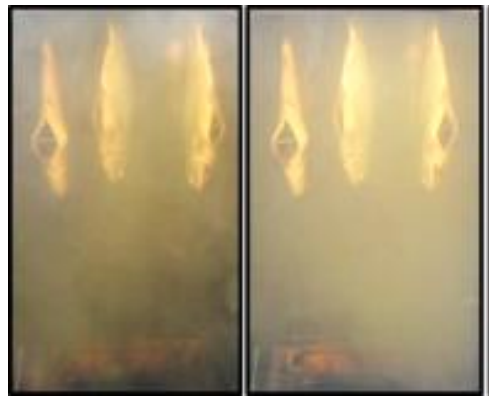

$\mathrm{t}=6 \mathrm{~s}$

$\mathrm{t}=12 \mathrm{~s}$ c. Bahan bakar briket ampas tebu (195 gram)

Gambar 5. Distribusi asap pada proses pemanasan dari $\mathrm{T}_{\text {Ruang }}-80^{\circ} \mathrm{C}$

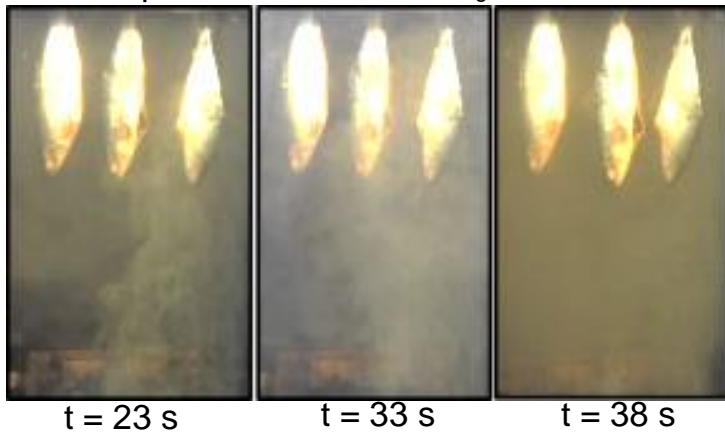

a. Bahan bakar tempurung kelapa (45 gram)

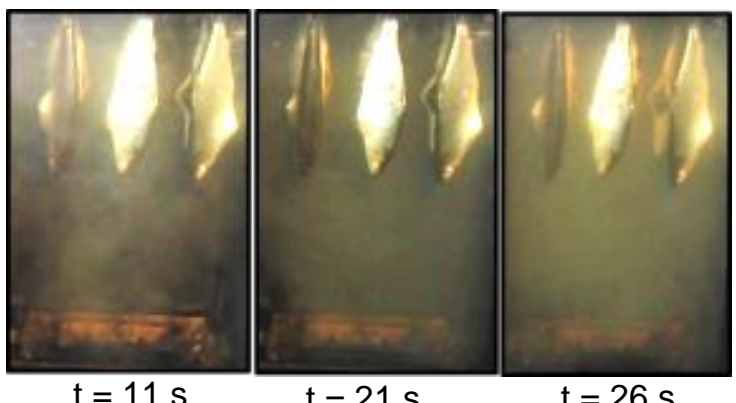

b. Bahan bakar tempurung kelapa (50 gram)

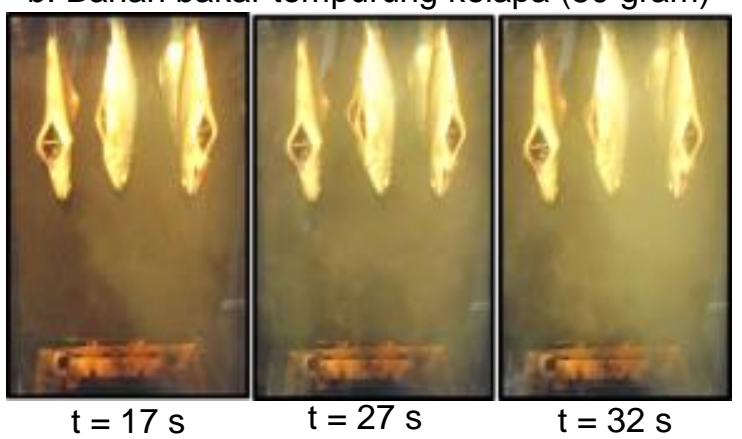

c. Bahan bakar briket ampas tebu (75 gram)

Gambar 6. Distribusi asap pada proses pengasapan dengan temperatur setting $80^{\circ} \mathrm{C}$
Distribusi asap hasil pembakaran bahan bakar di dalam ruang bakar selama proses pemanasan dan pengasapan pada temperatur $80^{\circ} \mathrm{C}$ berturut-turut dapat dilihat pada Gambar 5 dan Gambar 6.

Gambar 5a - 5c menunjukkan banyaknya jumlah asap pada saat pembakaran untuk menaikkan temperatur ruang pengasapan dari $29^{\circ} \mathrm{C}$ atau $30^{\circ} \mathrm{C}$ menjadi $80^{\circ} \mathrm{C}$. Saat $\mathrm{t}=0$ adalah waktu awal bahan bakar menyala di dalam dapur, saat masih belum terbentuk asap. Gambar ini menunjukkan bahwa jumlah asap pada pembakaran serabut kelapa dan briket ampas tebu relatif sama, tetapi jumlah asap pada pembakaran tempurung kelapa relatif sedikit. Selanjutnya terlihat bahwa jumlah asap pada pembakaran tempurung kelapa relatif stabil. Dimana serabut kelapa diwaktu awal pembakaran menghasilkan asap yang lebih banyak, tetapi setelah mencapai waktu tertentu asap mulai berkurang. Sedangkan bahan bakar tempurung kelapa memiliki jumlah asap yang relatif tetap selama proses pembakaran. Jumlah asap pada pembakaran ampas tebu relatif lebih banyak dan terdistribusi lebih merata di dalam ruang pengasap dibandingkan jumlah asap pada pembakaran tempurung kelapa dan serabut kelapa.

Gambar 6 menunjukkan jumlah dan distribusi asap pada proses pengasapan pada temperatur konstan $\pm 80^{\circ} \mathrm{C}$. Dalam gambar ini waktu $\mathrm{t}=0$ adalah waktu terjadi pengumpanan atau penambahan bahan bakar. Gambar ini menunjukkan bahwa pada saat pengasapan pada temperatur konstan $\pm 80^{\circ} \mathrm{C}$ jumlah gas asap relatif lebih sedikit dibandingkan pada saat pemanasan. Hal ini disebabkan jumlah bahan bakar yang dibakar pada proses pengasapan lebih sedikit dari pada saat proses pemanasan. Sehingga jumlah gas hasil pembakaran yang dihasilkan juga lebih sedikit. Selain jumlah bahan bakar, jumlah asap juga dipengaruhi oleh kerapatan partikel bahan bakar, ketersediaan udara pembakaran dan kelembaban udara. Apabila jumlah bahan bakar lebih banyak dari oksigen yang tersedia didalam ruang bakar untuk proses pembakaran maka kecepatan pembakaran 
menjadi kecil sehingga asap yang dihasilkan menjadi banyak karena bahan bakar tidak terbakar sempurna. Gas asap timbul karena terjadinya reaksi pembakaran bahan bakar dan udara yang tidak seimbang / stoikiometri. Demikian juga dengan kerapatan partikel pada bahan bakar, semakin padat / rapat partikel pada bahan bakar maka kecepatan pembakarannya menjadi kecil sehingga waktu yang dibutuhkan untuk terbakarnya bahan bakar menjadi lebih lama. Selain itu kelembaban udara yang tinggi juga akan menghasilkan asap yang banyak [7]. Selanjutnya dapat dilihat bahwa untuk mendapatkan distribusi asap yang merata di dalam ruang pengasap memerlukan waktu yang lebih lama dibandingkan pada saat pemanasan. Hal ini juga berhubungan dengan jumlah bahan bakar yang dibakar.

Secara umum kecenderungan jumlah dan distribusi asap dalam ruang pengasap pada saat pengasapan sama dengan pada saat pemanasan untuk menaikan temperatur menjadi $80^{\circ} \mathrm{C}$. Pembedanya adalah jumlah asap yang relatif lebih sedikit dibandingkan jumlah asap pada saat pemanasan.

Kualitas ikan hasil asapan dengan menggunakan 3 jenis bahan bakar dapat dilihat pada Gambar 6 dan 7. Gambar 7a - 7c menunjukkan ikan bandeng hasil asapan dengan menggunakan 3 variasi jenis bahan bakar yang berbeda yaitu tempurung kelapa, serabut kelapa dan briket ampas tebu. Secara visual ikan mempunyai penampakan yang relatif tidak berbeda. Untuk mengetahui kualitas ikan bandeng secara detail dilakukan pengujian proksimate (meliputi pengujian kadar air, kadar abu, kandungan protein dan lemak) dan pengujian organoleptik (meliputi penilaian terhadap kenampakan, bau, rasa dan tekstur). Hasil pengujian ditunjukkan paga Gambar 8a dan 8b.

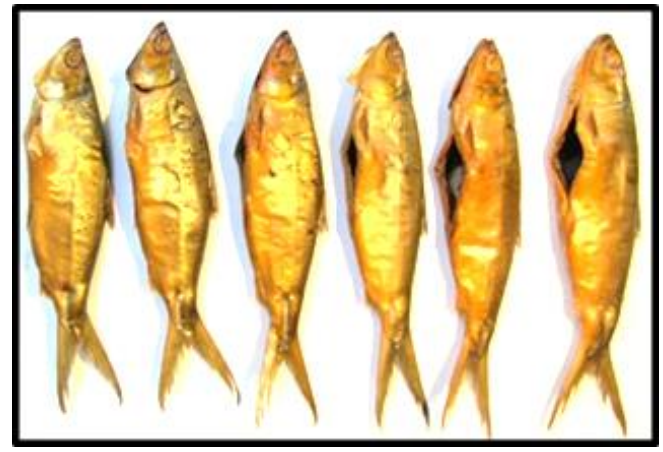

a. Bahan bakar tempurung kelapa

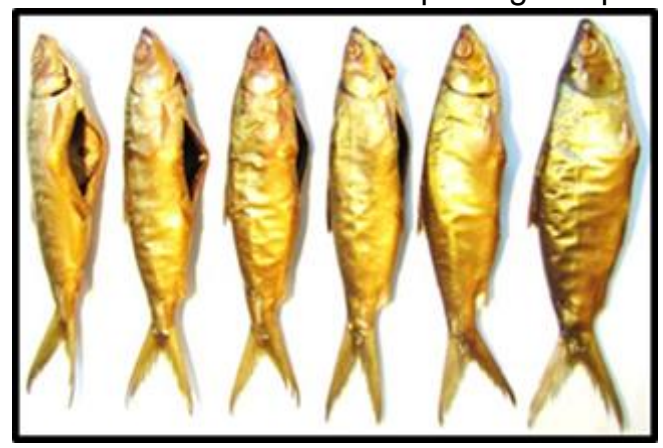

b. Bahan bakar serabut kelapa

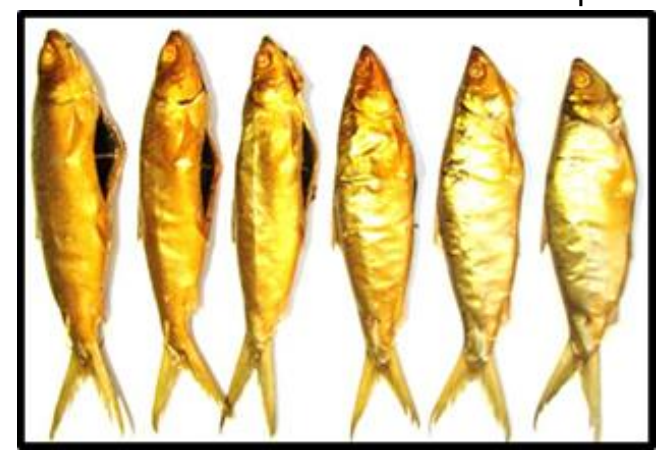

c. Bahan bakar briket ampas tebu

Gambar 7. Produk hasil asapan ikan bandeng dengan variasi bahan bakar

Pada pengujian proksimate didapatkan bahwa ikan bandeng asap dengan menggunakan bahan bakar tempurung kelapa memiliki kadar air paling rendah dibandingkan dengan bahan bakar serabut kelapa dan briket ampas tebu yaitu $56,91 \%$, sedangkan kadar air untuk ikan bandeng asap dengan bahan bakar serabut kelapa dan briket ampas tebu relatif sama, berturut - turut sebesar 58,32\% dan $58,37 \%$. Kandungan air pada ikan bandeng asap dengan bahan bakar tempurung 
kelapa memiliki prosentase yang paling rendah menunjukkan proses pembakaran dan disebabkan karena tempurung kelapa memiliki pengasapan yang efisien. Berdasarkan SNI nilai kalor yang paling tinggi dibandingkan 2736.1.2009 tentang ikan asap menunjukkan serabut kelapa dan briket ampas tebu, dan bahwa kadar air maksimal pada ikan asap tempurung kelapa memiliki kepadatan yang adalah 60\%. Dapat disimpulkan penggunaan tinggi sehingga kecepatan pembakarannya bahan bakar alternatif menghasilkan ikan menjadi lebih rendah. Kombinasi kedua sifat dengan kadar air yang memenuhi kualifikasi tersebut menghasilkan temperatur ruang asap SNI.

yang relatif tinggi dan lebih stabil (fluktuasi (emperaturnya lebih rendah). Hal ini serabut kelapa memiliki kadar abu yang paling menghasilkan kondisi pengeringan yang besar yaitu 3,02\%, sedangkan ikan bandeng efisien, sehingga kadar air dalam ikan asap asap dengan menggunakan bahan bakar menjadi lebih kecil.

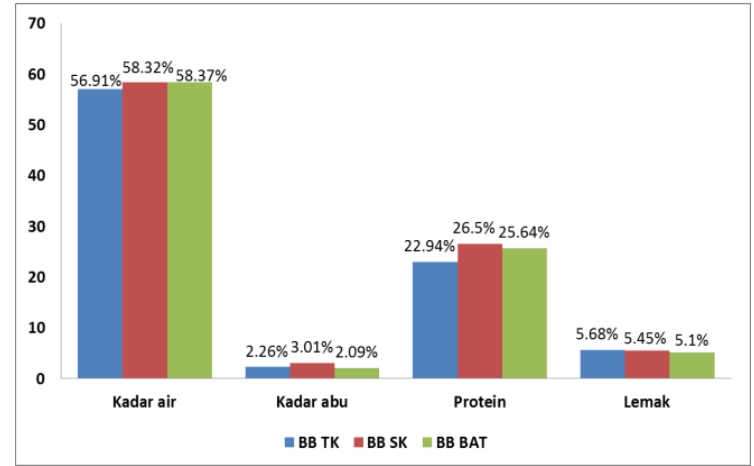

a. Pengujian proksimate

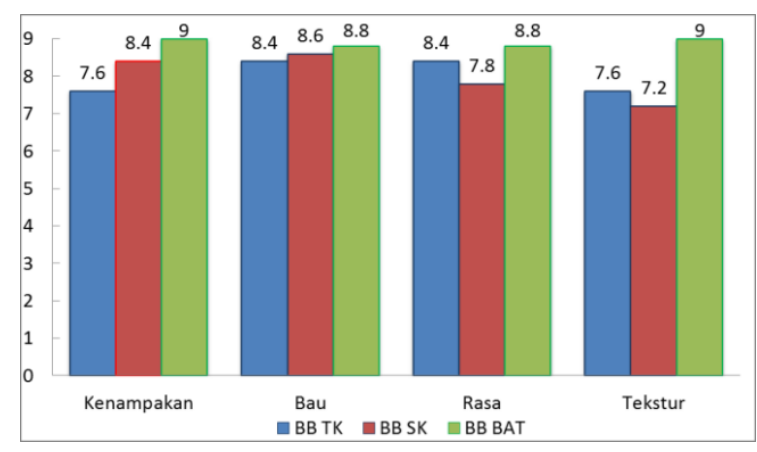

b. Pengujian organoleptik

Gambar 8. Hasil pengujian ikan bandeng asap

Berdasarkan nilai kalor bahan bakar dan massa total bahan bakar untuk proses pengasapan, jumlah kalor yang paling banyak ke paling sedikit berturut - turut dimiliki oleh bahan bakar briket ampas tebu, serabut kelapa dan tempurung kelapa. Walaupun demikian pengasapan ikan dengan bahan bakar tempurung kelapa menghasilkan ikan dengan kadar air paling rendah. Hal tersebut tempurung kelapa dan briket ampas tebu memiliki kadar abu relatif sama secara berturut-turut yaitu 2,26\% dan 2,09\%. Kadar abu pada ikan merupakan residu organik dari proses pembakaran komponen organik bahan pangan. Kadar abu dari suatu bahan pangan menunjukkan total mineral yang terkandung dalam bahan pangan tersebut. Berdasarkan SNI 2725.1.2009 tentang ikan asap bahwa kadar abu kurang dari pada ikan asap sebesar $4 \%$. Penggunaan semua jenis bahan bakar dalam penelitian ini menghasilkan ikan dengan kadar abu yang memenuhi kualifikasi SNI.

Kandungan protein pada ikan bandeng asap dengan bahan bakar serabut kelapa dan briket ampas tebu relatif sama yaitu $26,5 \%$ dan $26,64 \%$ sedangkan ikan bandeng asap dengan menggunakan bahan bakar tempurung kelapa memiliki kadar protein paling rendah yaitu $22,94 \%$. Kandungan protein pada ikan asap diharapkan mengalami pengurangan yang tidak signifikan pada bandeng asap tersebut. Diharapkan masih dalam prosentase kandungan protein pada ikan bandeng segar yaitu antara $20 \%$ - 30\%. Pada ikan bandeng asap dengan bahan bakar tempurung kelapa memiliki prosentase kandungan protein yang paling rendah. Hal ini disebabkan oleh pemanasan yang efisien pada pengasapan dengan bahan bakar tempurung kelapa, sebagaimana dijelaskan pada bagian sebelumnya, mengakibatkan penguraian protein yang lebih besar, sehingga kadar proteinnya lebih rendah.

Prosentase kandungan lemak pada ikan bandeng asap dari ketiga bahan bakar yaitu tempurung kelapa, serabut kelapa dan briket 
ampas tebu relatif sama secara berturut-turut kompak, cukup kering dan antar jaringan erat. yaitu 5,68\%,5,45\% dan 5,1\%. Berdasarkan Sedangkan ikan bandeng asap dengan bahan SNI 2725.1.2009 tentang ikan asap bakar tempurung kelapa dan serabut kelapa menunjukkan bahwa kandungan lemak relatif sama yaitu berturut-turut 7,6 dan 7,2 maksimal pada ikan asap adalah 6\%. Dapat dimana tekstur ikan padat, kompak kering dan dikatakan bahwa produk ikan asap yang antar jaringan erat. Berdasarkan SNI 2725.1.9 dihasilkan dalam penelitian ini semua tentang ikan asap, nilai rata-rata minimal untuk memenuhi kualifikasi SNI 2725.1.2009 tentang pengujian organoleptik adalah 7 [8]. Sehingga kandungan protein dan lemak. nilai pengujian organoleptik seluruh ikan

Pengujian organoleptik yang meliputi bandeng asap yang dihasilkan dalam kenampakkan, bau, rasa dan tekstur pada ikan pengujian ini memenuhi Standar Nasional bandeng asap berupa kuisioner yang diisi oleh Indonesia 2725.1.9. Dapat dilihat bahwa 10 penguji. Nilai dari hasil pengujian tersebut pengasapan dengan bahan bakar briket dirata-rata pada setiap uraian jenis pengujian. ampas tebu memiliki nilai uji organoleptik yang Hasil pengujian organoleptik dapat dilihat pada paling tinggi dibandingkan bahan bakar Gambar 7b. Hasil pengujian menunjukkan lainnya.

bahwa ikan bandeng asap dengan bahan bakar briket ampas tebu memiliki nilai kenampakan 9 dimana secara fisik utuh, bersih dan memiliki warna coklat sangat mengkilat. Sedangkan nilai kenampakan ikan bandeng asap dengan bahan bakar tempurung kelapa dan serabut kelapa relatif sama, berturut-turut 8,4 dan 7,6, dimana secara fisik utuh, bersih dan mengkilat. Penilaian indra pencium/bau didapatkan bahwa untuk ikan bandeng asap dengan ketiga jenis bahan bakar yaitu tempurung kelapa, serabut kelapa dan briket ampas tebu adalah relatif sama, berturut-turut sebesar 8,$4 ; 8,6 ; 8,8$ dimana bau ikan bandeng asap dari ketiga macam jenis bahan bakar memiliki aroma kurang harum, asap cukup dan tanpa bau tambahan yang menggangu.

Ikan bandeng asap dengan ketiga jenis bahan bakar tempurung kelapa, serabut kelapa dan briket ampas tebu memiliki nilai rasa yang relatif sama secara berturut-turut adalah 8,$4 ; 7,8 ; 8,8$. Dimana dari ketiga ikan bandeng asap tersebut memiliki rasa enak tetapi kurang gurih. Pada Ikan bandeng asap dengan bahan bakar briket ampas tebu memiliki rasa cenderung manis dan asin, sedangkan ikan bandeng asap dengan bahan bakar tempurung kelapa dan briket ampas tebu memiliki rasa cenderung asin. Tekstur ikan bandeng asap dengan bahan bakar briket ampas tebu memiliki nilai yang paling tinggi yaitu 9, dimana tekstur ikan cukup padat,

\section{KESIMPULAN}

Berdasarkan data yang diperoleh dari hasil penelitian maka dapat disimpulkan bahwa jumlah bahan bakar yang dibutuhkan untuk mendapatkan temperatur ruang pengasap yang sama adalah dengan jumlah bahan bakar yang berbeda, tergantung nilai kalor bahan bakar, kerapatan partikel bahan bakar, kecepatan pembakaran dan heat loss dari ruang bakar ke lingkungan. Jumlah total bahan bakar tempurung kelapa, serabut kelapa dan briket ampas tebu selama pemanasan untuk mencapai temperatur $80^{\circ} \mathrm{C}$ dan untuk proses pengasapan pada suhu \pm $80^{\circ} \mathrm{C}$ secara berturut turut sebanyak 1045 gram, 1730 gram dan 2070 gram. Distribusi temperatur pada setiap posisi peletakan ikan dan karena perbedaan jenis bahan bakar relatif kecil, sehingga dapat menghasilkan ikan asap yang memenuhi Standar Nasional Indonesia 2725.1.9.

Bahan bakar briket ampas tebu menghasilkan jumlah asap yang paling banyak dan distribusi yang merata di dalam ruang pengasap. Hal ini disebabkan jumlah bahan bakar yang lebih banyak dan jumlah oksigen yang kurang. Selain itu peletakan bahan bakar dan fungsi dari pengarah asap pada ruang bakar sangat mempengaruhi tingkat keseragaman distribusi asap dalam ruang pengasap. 
Kualitas hasil asapan ikan bandeng dengan menggunakan variasi bahan bakar yaitu tempurung kelapa, serabut kelapa dan briket ampas tebu secara keseluruhan masih memenuhi SNI 2725.1.2009 tentang ikan asap. Selanjutnya pengasapan dengan bahan bakar ampas tebu menghasilkan nilai uji organoleptik yang paling tinggi.

\section{DAFTAR PUSTAKA}

[1] Chakraverty, 1991, Post Harvest Tecnology of Cereal and Pulses Drying Tecnology Journal, New Delhi, Vol. 9, No. 2, 527-528.

[2] Nawawi, Zamanhuri, Napitupulu, Syuhada, 2008, Kajian Karakteristik Perpindahan Panas Pada Ruang Sistem Pengering / Pengasapan dengan Energi Panasa dari Bahan Bakar Jurnal Polimesin, Politeknik Negeri Lhokseumawe, Vol. 9, No. 9, 532 - 544.

[3] Irawan, 1997, Pengawetan dan Pengolahan Ikan, CV. Aneka, Solo.
[4] Sujud, 2013, Potensi Kerajinan Tempurung Kelapa, Dinas Pendidikan dan Kebudayaan, Pekalongan.

[5] Komar, 2001, Penerapan Pengasapan Ikan Laut Bahan Bakar Tempurung Kelapa Jurnal Teknologi Pertanian, Universitas Brawijaya Malang, Vol. 2, No.1, 58-67.

[6] Malakauseya, Sudjito, Mega, 2013, Pengaruh Prosentase Campuran Briket Limbah Serbuk Kayu Gergajian dan Limbah Daun Kayu Putih terhadap nilai kalor dan kecepatan pembakaran Jurnal Rekayasa Mesin, Universitas Brawijaya Malang, Vol. 4, 194-198.

[7] Wardana, 2008, Bahan Bakar dan Teknologi Pembakaran, PT. Danar Wijaya, Brawijaya University Press, Universitas Brawijaya Malang.

[8] SNI 2725.1, 2009, Standar Nasional Indonesia tentang Ikan Asap, Badan Standarisasi Nasional, Jakarta. 